\title{
Hidden features in global knowledge production: (re)positioning theory and practice in academic writing
}

\author{
Características ocultas na produção \\ de conhecimento global: (re)posicionando \\ teoria e prática na escrita acadêmica
}

Joel Windle*

Universidade Federal Fluminense

Niterói, Rio de Janeiro / Brasil

Monash University

Melbourne / Austrália

\begin{abstract}
A key challenge for applied linguistics is how to deal with the historical power imbalance in knowledge production between the global north and south. A central objective of critical applied linguistics has been to provide new epistemological foundations that address this problem, through the lenses of post-colonial theory, for example. This article shows how the structure of academic writing, even within critical traditions, can reinforce unequal transnational relations of knowledge. Analysis of Brazilian theses and publications that draw on the multiliteracies framework identifies a series of discursive moves that constitute "hidden features" (STREET, 2009), positioning "northern" theory as universal and "southern" empirical applications as locally bounded. The article offers a set of questions for critical reflection during the writing process, contributing to the literature on academic literacies.
\end{abstract}

KEYWORDS: Epistemology; critical applied linguistics; globalisation; postcolonial theory; multiliteracies; academic literacies.

RESUMO: Um dos principais desafios da Linguística Aplicada é como lidar com o desequilíbrio de poder entre os países do "norte" e do "sul" global na produção de conhecimento. Um objetivo central da Linguística Aplicada Crítica tem sido providenciar novas bases epistemológicas para enfrentar esse problema, por meio de perspectivas pós-coloniais, por exemplo. Este artigo mostra como a estrutura da escrita acadêmica, mesmo dentro de tradições críticas, pode reforçar relações de conhecimento desiguais. A análise de teses e publicações brasileiras que se apoiam no quadro teórico dos multiletramentos

*jawindle@gmail.com 
identifica uma série de movimentos discursivos que configuram "elementos ocultos" (STREET, 2009), posicionando a teoria do "norte" como universal e aplicações empíricas no "sul" como localmente restritas. O artigo oferece um conjunto de perguntas para reflexão crítica durante o processo de escrever, contribuindo à literatura sobre letramentos acadêmicos.

PALAVRAS-CHAVE: Epistemologia, linguística aplicada crítica, globalização, teoria pós-colonial, multiletramentos, letramentos acadêmicos.

\section{Introduction}

Moves towards a critical applied linguistics have placed recognition of the political, social and cultural processes of globalisation front and centre (PENNYCOOK, 2001; RAJAGOPALAN, 2003; PENNYCOOK, 2010; IYER et al., 2014). One of the important contributions of such moves is the notion that knowledge is political, situated and constitutive of relations of power. The foregrounding of the politics of power and knowledge provides a valuable way of reflecting on the epistemological dimensions of unequal global relations in academic production in the field of applied linguistics. Such reflections are important in the context of the global dominance of US and European universities, publishing houses and conceptual frameworks (CANAGARAJAH, 2002; KUMARAVADIVELU, 2006; CONNELL, 2007; MIGNOLO, 2012).

Pennycook (2001) distinguishes four epistemological stances in critical applied linguistics. The first seeks to identify universal linguistic structures, following the positivist models of the natural sciences in which both researcher and research object are divorced from political concerns. This stance is critical in the sense that it favours descriptive over prescriptive or normative approaches to language, treating all phenomena democratically, without value judgements. A second position espouses a humanist universalism, in which radical political activity is necessary, but remains divorced from scientific endeavours (Chomski being the chief example). In these two perspectives, the universal often masks European or American parochialism. A neo-marxist epistemological framework, by contrast, sees ideology and the interests of capital at work in language, but, according to Pennycook, remains uncritical of its own truth claims. Researchers risk seeing themselves as outside of power relations; as an enlightened few seeking to emancipate the rest with "scientific" knowledge. A final epistemological stance, drawing on post-structuralism and post-colonialism, 
"articulates a profound scepticism about science, about truth claims, and about an emancipatory position outside ideology" (PENNYCOOK, 2001, p. 42). It is this final position that Pennycook himself advocates.

Pennycook criticises neo-Marxist perspectives as relying on a crude dichotomy of oppressed-oppressors, ignoring the more complex operations of "micro-power." He sets up a fairly stark division between "modernist" neo-Marxists and a post-colonial "problematizing" epistemology, which he views with a more positive eye. This perhaps overstates the distance of some foundational postcolonial work from Marxist premises of oppressive class (and colonial) interests being served by scientific knowledge (SPIVAK, 1988; APPADURAI, 1990; SAID, 1995; SPIVAK, 1999; MIGNOLO, 2003; 2009). Connell's (2007) survey of southern theories also favour frameworks that account for, and are forged by struggles against, the macro-relations of oppression in ways that echo Marxist analyses.

My argument here is that, almost independent of stated epistemological frameworks, the structures of academic writing themselves produce epistemological effects. Academic production is heavily constrained by the accumulated weight of macro-power structures, as well as the micro-power structures of linguistic form and style. In the context of contemporary academic production, it is therefore crucial to pay attention to processes of colonial and neocolonial domination that work through the imposition of norms and decisions around academic writing (CANAGARAJAH, 2002). Part of Connell's call for southern epistemologies is based on embracing forms of writing from outside traditional academic genres. Academic writing is the natural home of "traditional intellectuals", thoroughly institutionalised and apparently above the cut and thrust of politics, rather than the "organic intellectuals" thrown up by direct involvement in social struggles (GRAMSCI, 1971). Following Gramsci, Connell (2007) favours epistemologies developed by the organic intellectuals of oppressed groups, particularly in contexts of struggle against colonial or neocolonial oppression. This is similar to the project laid out by Mignolo, who seeks epistemologies that are distinctive to regions that are oppressed within the global system, as part of a process of decolonising knowledge (MIGNOLO, 2012).

The remainder of the article provides an analysis of the multiliteracies framework as a form of global knowledge production, as well as examining how the framework travels to Brazil and appears in Brazilian academic production. I first came into contact with the term multiliteracies while undertaking my graduate diploma of teaching in Australia, which included 
a lecture on multiculturalism from Mary Kalantzis, then as a secondary school language teacher and later through work designing second language pedagogy for refugee-background students (WINDLE; MILLER, 2012). These Australian contexts are familiar to - and shaped the world views of - the Australian framers of multiliteracies, including Bill Cope, Mary Kalantzis, Alan Luke and Martin Nakata (THE NEW LONDON GROUP, 1996; COPE; KALANTZIS, 2000). When I began living in Brazil, and came to be closely involved in the work of the São Paulo-Campinas multiliteracies "circle", I started to notice that some uses of the framework made me uncomfortable, especially due to slippages in the meaning of terms such as "multicultural." The Brazilian work positioned itself within a framework that I understood as describing a quite different sort of society. This unease has provoked the present contribution, which seeks to examine some of the epistemological challenges facing the emerging field of critical applied linguistics (PENNYCOOK, 2010; IYER et al., 2014). My purpose is not to test the applicability or relevance of the multiliteracies framework in Brazil, but rather to analyse how truth claims are constructed and positioned in academic production in applied linguistics. The concept of multiliteracies is taken as representing an important strand of critical applied linguistics, sitting alongside traditions such as critical literacy and critical discourse analysis.

To this end, I extend the notion of "hidden features" in academic writing (STREET, 2009), with the aim of providing strategies that can contribute to repositioning theoretical and empirical framings in global scholarly production. In Street's work, hidden features are textual elements that are used to judge academic writing, but remain implicit, and hence generally unrecognised and untaught. However, some textual elements are so well hidden that they remain invisible to both evaluators and writers, constituting underlying epistemological assumptions that structure the academic field. The features I focus on here are the spatial and historical positioning of theory in relation to three fields: the field in which the theory was generated, the field in which the writer is located and from which they speak, and the field into which the writer seeks to speak. With pressure on higher education systems to internationalise, including in Brazil, hidden features of academic literacy that promote the dominance of northern perspectives need to be made explicit and addressed.

While critiques of the dominance of northern theory are now well established, this article also seeks to show how the "global perspective" 
becomes embedded in the discursive practices of academic writing. The analysis is based on a close reading of the original New London Group multiliteracies manifesto, and a corpus of Brazilian academic and postgraduate writing. In focusing on (re)positioning, I draw on Hyland's notion of stance, taken up by Street, as "the ways that writers project themselves into their texts to communicate their integrity, credibility, involvement, and a relationship to the subject matter and their readers" (HYLAND, 1999, p. 99).

\section{Critiques of the "global perspective"}

The contention of this article is that even critical epistemologies in applied linguistics are epistemologically committed to a narrative of unified global, social and technological change, connected to similarly unified economic transformations such as "fast capitalism" (GEE; HULL; LANKSHEAR, 1996). However, the narrative of global social change (the "global perspective") is actually constructed from the perspective of the global north or "metropole" (CONNELL, 2008). Failure to acknowledge this is part of a set of hidden social relations in global knowledge production (SOUSA SANTOS; LEITE, 2010). In relation to this, Connell (2007, p. 66) observes that "a system of categories is created by metropolitan intellectuals and read outwards to societies in the periphery, where the categories are filled in empirically.” For Sousa Santos, arguing a similar position, globalisation is:

The scale that privileges entities or realities that widen their scope to the whole globe, thus earning the prerogative to designate rival entities as local. According to this logic, nonexistence is produced under the form of the particular and the local. The entities or realities defined as particular or local are captured in scales that render them incapable of being credible alternatives to what exists globally and universally. (SOUSA SANTOS , p. 16-17).

The theory of a global society emerged in social science scholarship of the 1990s, based on the idea of a breaking down of boundaries and intensification of connections through "abstract linkage" (CONNELL, 2007). Connell notes that many theorists recycled work on postmodernism, complexity and diversity, which they had developed on national scales, by claiming that these now applied on a world scale. She argues that the characteristics of global society are: 
[...] based on concepts that have previously been worked out, not for speaking about colonies, empires or world affairs, but for speaking about metropolitan societies - that is, the cluster of modern, industrial, postmodern or postindustrial countries that had been the focus of theoretical debates in sociology for decades before. (CONNELL, 2007, p. 55).

Even notions of increased diversity, and its hyped relative "superdiversity", are focused on developed nations that have received recent intakes of migration and the most visible aspects of the changed linguistic landscape (BLOMMAERT; RAMPTON, 2011; PAVLENKO, 2014). Pavlenko (2014) suggests that the association of globalisation with increased diversity ignores the increased homogeneity that emerges in some settings from which migrants are drawn, and the need for a more rigorous study of diversity in language beyond the metropolis.

Another critique that may be broadly levelled against even the "problematizing" frameworks advocated by Pennycook is that they underplay non-discursive forms of power that are more heavily present in the global "south" (CANAGARAJAH, 2002; ESCOBAR, 2004). As Connell (2007, p. 378) writes, "the shared experiences of metropolitan theorists and metropolitan readers do not include much of the sharp end of global social processes." Indeed, the local and global relations established in Brazil, including racial inequality, are heavily shaped by a long and continuing history of actual physical, rather than merely symbolic, violence. There were over 58,000 violent deaths in Brazil in 2014 - the great majority caused by murder, with killings by police being the second most common cause (REUTERS, 2015). More Brazilians die at the hands of police than in armed robberies (FORUM BRASILEIRO DE SEGURANCA PUBLICA, 2015). Violence is greatest in the northeast, and its victims are overwhelmingly young, poor, black, male and residents of urban peripheries, facts that are central to a politically engaged Brazilian sociolinguistics (BAGNO, 1999, 2014; LUCCHESI, 2015).

One only needs to compare cinematic portrayals of delinquent children - French New Wave classic Les 400 coups (1959) or Australia's larrikin Fast Talking (1984) to the Brazilian Pixote: a lei do mais fraco (1980) to get a sense of the contrast in the kinds of violence shaping childhood in different societies. While the protagonist of Truffaut's French masterpiece is undone by plagiarising Balzac, and the substitute teacher in Australia's Fast Talking wonders if her trouble-making students speak the same language 
as her, Pixote portrays unrelenting torment endured by homeless, black and transgendered youth in the darkest days of the military dictatorship. The film is surely one of the most devastating portrayals of brutality and desperation ever produced, its realism reinforced by the real-life death of its star, shot dead by police at age 19 .

The continuation of straight-out, coercive imperialism is also downplayed in academic work that cultivates a "global perspective" on new networks and discursive formations. The "sharp end" of imperialism was all too visible when a waste dam owned by the world's two largest mining companies burst in 2015, killing close to thirty villagers in the Brazilian town of Mariana and destroying a major river system. The companies, BHP and Vale, were able to rely on massive political and economic influence to remain effectively unregulated, unpunished and without compensating its victims, many of whom were subsistence farmers. These are not the relations of new "fast capitalism", but a continuation of the extraction of vast riches that dates back 500 years, a form of exploitation that funded the industrial revolution in northern Europe (GALEANO, 2009). But even within global metropoles, such as the US, discursive strategies of domination are often dispensed by government and big capital in favour of direct coercion when it comes to "disposable" populations, such as Black and Latino communities (LIPMAN, 2011).

The global perspective on the spread and privileging of official languages through the expansion of formal schooling, including as part of colonial projects, is an example of a globalising narrative that hides other more violent and non-discursive social processes. The establishment of Portuguese as the most widely spoken language in Brazil initially came about not through the development of a national school system and standards, but rather from the massive, and bloody, movement of slave labour to the gold-fields in Minas Gerais in the early 1700s, together with an influx of Portuguese migrants (LUCCHESI, 2003; 2015). It is ironic that now the Portuguese of the poor inhabitants of the Minas Gerais district of Bento Rodrigues destroyed by the 2015 mining waste dam collapse is considered to be so divergent from the norm that its speakers are subtitled in videos produced by alternative media activists. Certainly, the transnational and multilingual campaign in defence of the victims of the disaster, including those produced by schools and university students (https:/ /www.facebook. com/MarianaInfo1.0/), could be usefully analysed using "global" critical 
applied linguistics perspectives. However, such an analysis would miss important elements of both the power relations that produced the disaster and those that provided BHP/Vale with economic and political protection against its victims' protests.

\section{Hidden features in the multiliteracies framework}

Multiliteracies is a prominent example of global academic production aligned with critical applied linguistics (THE NEW LONDON GROUP, 1996; COPE; KALANTZIS, 1999; 2000). First presented in 1996, the founders set out a "programmatic manifesto" that provides: "a theoretical overview of the current social context of learning and the consequences of social changes for the content (the "what") and the form (the "how") of literacy pedagogy" (THE NEW LONDON GROUP, 1996, p. 63).

The authors seek to overcome educational barriers linked to linguistic, cultural and gender differences by promoting a vision of diversity defined through pluralism and flexibility to move between life-worlds. Of the social field within which they situate themselves, Cope and Kalantzis write:

The kind of person who can live well in this world is someone who has acquired the capacity to navigate from one domain of social activity to another, who is resilient in their capacity to articulate and enact their own identities and who can find ways of entering into dialogue with and learning new and unfamiliar social languages. (COPE; KALANTZIS, 2009, p. 173-174).

Updating their initial 1995 formulation, Cope and Kalantzis observe:

We have found that the basic shape of our original position has stood the test of time. In fact, it has proved to be a useful guide to understanding and practice - the centrality of diversity, the notion of design as active meaning making, the significance of multimodality and the need for a more holistic approach to pedagogy. (COPE; KALANTZIS, 2009, p. 167).

The multiliteracies framework allows for considerations of some of the political dilemmas caused by the tension between the need to reinvent the nation state from its colonial past (both domestic and overseas) and the demands of a global economy that is intent on making the nation state irrelevant. These include the linguistic incorporation (or exclusion) of migrants and refugees into a national community and competition for 
jobs on an international scale. However, it also leaves other epistemological dilemmas unresolved, such as the clash between a modernist and a postmodernist view of violence and coercion, the former decrying abuses of physical power, the latter decrying abuses of symbolic and discursive power.

Foundational multiliteracies work, as well as academic production coming out of Brazil, reflects a number of the problems identified in critiques of global knowledge production in a more general sense. Some of these relate not merely to questions of theoretical stances, but also to the structures of academic writing as a field in which some positions are marked, while others remain unmarked (CANAGARAJAH, 2002). The locus of enunciation of the original manifesto in The Harvard Educational Review is unmarked, and is generally uncommented on in later work (THE NEW LONDON GROUP, 1996). Subsequent authors making use of the manifesto do not draw attention to the fact that it was written, in the first instance, to appeal to an editorial board comprised entirely of postgraduate students at one of the United States' (and the world's) most exclusive universities. What this board considers to be "education's most vital issues" are published in the Review. The manifesto, therefore, implicitly performs theoretical work primarily considered relevant to the US intellectual field and education system.

The manifesto positions itself in a global space defined by change, with terms including "the changing social environment", "the world today", "our society", "the overall communications environment", "communication channels and media supports", "the context of ever more critical factors of local diversity and global connectedness", "the context of cultural and linguistic diversity", "our current changing environment", "the emerging reality", "the world of the imminent future", "the world", "the new environment of literacy education", "the contemporary world", "we humans" and "an economy of productive diversity”(THE NEW LONDON GROUP, 1996).

The projected readers are implicitly positioned within, and as speaking about, the same social space as the authors. The universal claims mask over the fact that the authors are drawing together claims also previously made about specific contexts, particularly Australia. Cultural and linguistic diversity appear as recent phenomena, which indeed is true in the implicit context of post-war migration to Australia and migration to the USA throughout the twentieth century. The manifesto further argues that that literacy has been confined to "formalized, monolingual, monocultural and rule-governed 
forms of language" (THE NEW LONDON GROUP, 1996, p. 61). Again, this fits Australia and the US, but it is clear this claim does not hold over longer historical periods or for some existing multilingual practices.

On a descriptive level, it is hard to argue that diversity is not a universal fact, but the generalised expressions used in the Manifesto are somewhat hollow, with the examples leaving out essential considerations for understanding specific contexts. The forms of diversity evoked include women, indigenous peoples, immigrants and speakers of non-standard dialects. The descendants of enslaved peoples, a majority of the Brazilian population, for example, are not contemplated in this list. Expressions of solidarity, such as "we are all migrants", that circulate even within Brazil, ignore (or distort) the fact that the country was the destination for the largest forced movement of people in history (KLEIN, 2010). Historical work showing the centrality of slavery to the growth capitalism, as well as radical pedagogical critiques using critical race frameworks, offer more compelling, and situated, accounts of diversity within historically constructed power relations (HOOKS, 1994; BAPTIST, 2014; WILLIAMS, 2014). Neither slavery nor violence are mentioned in either the manifesto or the subsequent book-length exposition of the multiliteracies framework (THE NEW LONDON GROUP, 1996; COPE; KALANTZIS, 2000).

Hidden features of global academic production therefore establish the fiction of a single, globalised society in which social processes and change are comparable in all locations, and may be understood from a single "bird's eye" perspective. Further, they work to reduce academic production in the global south to the discovery of variations and new applications that confirm and enrich northern theory. The structural division between theory, setting and empirical sections in academic production is another practice that supports these hidden features. The most cited book on multiliteracies, for example, is divided into three sections on the "why", "what" and "how" of multiliteracies, written by authors from the US and Australia (COPE; KALANTZIS, 2000). A final section, "multiliteracies in practice", includes the only contributions from developing nations - two empirically-focused chapters from South Africa, out of a total of 16 chapters.

To summarise:

- Theorisation produced in the global north is geographically unmarked

- Applications of theory in the global north are geographically unmarked

- Applications of theory in the global south are geographically marked 
- Unity between the fields of theory production and application is provided by temporal marking of "a new era"

- Unity between the fields of theory production and application is provided by spatial marking of a global society.

- First person plural is used to join together fields of theoretical production and application.

\section{Limited and unlimited truth claims}

At this point, it may seem unfair to question a manifesto for being too abstract and general - it is the nature of the beast. However, it opens precisely the move that Connell (2007) critiques - the establishment of general categories (with unacknowledged reference to the "north"), and subsequent empirical "filling in." As the multiliteracies manifesto progresses, a number of subtle clues emerge that revise the truth claims made. Despite emphasising their own diversity, the New London Group are all from North America, the UK or Australia. In one passage, the authors acknowledge that their own experience, and the foundation of their proposal, relates to a single official language:

We agreed that in each of the English-speaking countries we came from, what students needed to learn was changing, and that the main element of this change was that there was not a singular, canonical English that could or should be taught anymore. (THE NEW LONDON GROUP, 1996, p. 63).

Some expressions clearly capture the tension between global claims and the limited scope of the global perspective: "we are living through a period of dramatic global economic change, as new business and management theories and practices emerge across the developed world" ( $p$. 65). The first half of the sentence suggests a universal claim, which in the second half is pulled back to changes only in the (minority) developed world. Importantly, the implications of management theories in the developed world are not made in relation to their effects on the developing world, but on the education systems of developed nations. This move effectively cuts off consideration of economic and management structures and schooling in the developing world. This limitation is evident further in the manifesto by the focus on paid employment in the formal economy, principally large 
corporations. Other forms of work, such as domestic labour, subsistence farming or work in the informal economy, are ignored. The very organisation of teachers' labour is radically different in education systems outside of developed nations.

In other parts of the Manifesto, there is also confusion between general and specific claims. At the end of a paragraph on global media fragmentation, the group writes of the demise of the "homogeneous imagined community of modern, democratic nation states" (p. 70). This suggests that the previous, apparently universal claims in the paragraph do not apply to the large portion of the world that does not fit this description. The examples provided reinforce the sense that the manifesto is only really about developed nations and a limited set of spaces, interactions and positions - the shopping mall, the casino, the therapeutic consultation with a doctor, the architect, the professional editor, and the home renovator.

With a compressed time-frame, at most stretching out to late colonialism, the manifesto argues that "interventionary states" used schooling to impose standardised national languages in the "Old World" and the "New World". However, in much of the colonised world, few efforts were made to educate local populations or impose a standardised language until the tail end of the colonial project, which even then was only limited to a small elite. For the first two hundred years of Portuguese colonisation in Brazil, for example, it was modified versions of Indigenous languages that dominated, were taught and were learnt by the colonists (LUCCHESI, 2015), rather than a standardised European language. Even after Portuguese came to dominate, the children of slaves were forbidden by law from attending school (ROMÃO; CARVALHO, 2003).

The New London Group further base their diagnosis of the changing world on a retreat from the welfare state (an implicit limitation to the more sweeping statements). However, this form of state was never a reality across most of the globe, and some contrary movements towards the construction of a welfare state can also be seen (as in Brazil, in the 13 years to 2016). Similarly, the Cold War appears to the New London Group to be an ideological battle, rather than a struggle for neocolonial domination over vassal states, as was the case in many developing nations.

The recent revival of right-wing nationalism, reflected in events such as Brexit and the election of Donald Trump, also signal that it is time to rethink whether the march of globalisation has reached a turning-point 
or moment of backlash, and therefore reconsider some of the founding propositions of the multiliteracies manifesto. Yet updates to the framework have tended to focus on technological developments since the original 1996 publication, whereas the overall statements of global convergence and increased cultural and linguistic heterogeneity and hybridity have remained unchallenged.

\section{Uptake of the multiliteracies framework in Brazil}

The movement of multiliteracies from the US to Brazil follows a broader pattern in which academic links are strongest with the global north, whereas south-south dialogues remain at the margins (LEITE, 2010; GOMES, ROBERTSON; DALE, 2012). The multiliteracies project has been well received by Brazilian scholars and even in public policy, shaping curriculum guidelines for foreign language teaching in secondary schools. The Brazilian Scielo academic database identifies 12 journal articles grounded in multiliteracies, but other sources suggest that this vastly underestimates the level of local academic production. The CAPES thesis database identifies 207 entries between 2013 and 2016, and at least five books have been published on the topic in the past five years. A congress on Critical Applied Linguistics in 2015 attracted 33 presentations drawing on the multiliteracies framework, and included keynotes by two of its founders (Bill Cope and Mary Kalantzis), as well as by one of its central Brazilian advocates (Walkyria Monte Mor). The thesis database reveals a concentration of work supervised and examined by professors located at the major public universities of São Paulo and Campinas, including Monte Mor, Lynn Mario de Souza, and Roxane Rojo.

The hidden features identified above in relation to the founding multiliteracies statements also hold true in Brazilian research. Remaining geographically unmarked, the mobilisation of multiliteracies in fact presents a bigger problem, because rather than merely overstating the reach of a theoretical framework, it is often taken up as if it were created specifically to describe Brazil. Student work often presents two distinctive rationales for research projects - the global changes identified by the founders of multiliteracies, and local public policy and legislation. The "local" rationale is given a sociohistorical and spatial context while multiliteracies remains as a general description of "the contemporary world". Projects seeking to engage with the idea of students as citizens, for example, do not note that 
citizenship, in the multiliteracies framework. is implicitly located within "modern, democratic nation states."

Many of the same expressions from the founding manifesto are reflected in Brazilian research, establishing a sense of spatial-temporal unity. The following examples of student writing ${ }^{1}$ show how this is accomplished (words in bold are my emphasis).

We know that the contemporary world is undergoing constant social transformation, driven by new means of communication and that conservative grammar-based perspectives have shown themselves incapable of supporting meaningful and effective teaching, in the most diverse educational segments and contexts.

The era that we are experiencing today is marked by ideas of flow, incompletion, transition and complexity and, for the authors cited above, in the educational field, the paradigm of reflexivity prevails, in which each subject must reflect critically on their actions in a world which prioritizes knowledge, jointly constructed in a transformative and ethical way.

We live in a society in which it is notable that human relations are in an active process of reconstruction, due to the processes of globalisation and to new communication and information technologies. Therefore, our society is globalized and changes quickly and continuously, the world becomes ever more "technologized" or "digitalised".

These kinds of statements are backed up by a citation of founding multiliteracies research, as the following example illustrates:

Cope and Kalantzis (2000), writing of the social, political and educational changes that we are experiencing in the present day, also discuss their educational impact.

The changes experienced by and motivating the founders of multiliteracies also establish the framework for evaluating Brazilian educational policy and practice:

\footnotetext{
${ }^{1}$ These examples are representative of some common patterns in student writing grounded in multiliteracies in the CAPES thesis database for the years 2013 and 2016. To avoid 'naming and shaming' junior researchers, the original Portuguese is not presented and sources are not identified."
} 
In this way, the [course studied] appears to meet, in the educational field, the new requirements of constantly changing network society.

School needs to adapt itself to this new social requirement in order to meet its educational objectives, amongst which is the creation of critical citizens able to operate in the most varied of social contexts.

Student work relies, almost exclusively, on these external references to build a portrait of "our society". Methodology sections are also presented as having validity by virtue of their fidelity to multiliteracies research. The "changing world" rationales and methodological procedures stand apart from dense descriptions of the Brazilian institutional and social context, in which Brazilian authors are more extensively cited. This "thick description" sometimes seeks connections with the theoretical framework of globalisation and fluidity, but risks leaving behind local issues, such as the configuration of urban socio-spatial inequalities, precarious public transport, or the fact that school dropout rates are at least five times greater than those in the generative contexts of the theoretical frameworks. Discussion of the implications of violence and slavery, missing from the original framework, remain almost entirely absent.

A further concern is related to the division of labour, in which theory is left untouched, even when it offers a weak foothold on important dimensions of the phenomenon being examined. For example, the metaphors for literacy learning of "the designer" and "design" used by the New London Group do not always travel well. Indigenous knowledge systems in which non-human entities are also conceived of as beings, present potential challenges to the design metaphor, which implies a world of objects or resources at the disposal of humans (DE SOUZA, 2006).

Design implies a level of control, visibility, stability, predictability and regulation that is far from the reality of life in the favela, for example, and this has potential implications for metaphorical extensions to learning environments as well. In favelas, construction is collaborative, negotiated, subject to the approval, support and acceptance of others, at the mercy of bureaucratic structures that consistently work against favela dwellers, provisional, and always vulnerable demolition, expropriation or repossession. A complex configuration of access through blocks of land, staircases, relatives' houses, territory controlled by drug cartels or corrupt police weighs on construction. Available materials and skills, the management of finances and debts, the joining together of friends and relatives to lay concrete for 
the foundations, all determine the rhythm of construction. The threat of landslides, other claims to the land or construction, the death or impairment of kin who support the construction, a sudden increase in stray bullets, a neighbour harbouring fugitives, all undermine efforts to establish a stable existence.

Some of these comments could easily be adapted to schooling. A better metaphor might be gambiarra, a Brazilian concept related to creatively improvising solutions, linked to popular cultures, and already theorised in the fields of art and media studies as an alternative to design (ROSAS, 2006; BOUFLEUR, 2007). The formal, visible Brazilian school system functions only through a symbiotic and often parasitic set of (hidden) parallel institutions that constitute a shadow education system (cram schools, language institutes, prep courses); as well as improvised solutions to precarious classroom conditions and delayed salaries. There is ample room, therefore, to rethink, retheorise and reposition theoretical constructs from multiliteracies such as design, including through local theoretical production that draws on existing "popular" concepts.

\section{Strategies for reflection on positionality in the academic writing process}

Global academic production, particularly through the cultivation of a "global perspective", produces the illusion of a shared deictic centre of time, space and person, establishing:

- Unified progression ("then", "now", "the future") denotes transition from industrial society to postmodern society.

- Subjective proximity ("Our, "us", "we" vs "them") denotes academia in global society, an unmarked member of a universal intellectual field vs native informants, outdated ideas and institutions.

- Spatial proximity ("here" vs "there") denotes the global city of the industrialised north in which English is the official language and into which "minorities" integrate vs small-scale societies that illustrate or demonstrate lessons from the metropole

The epistemological problems thrown up by global academic production within applied linguistics, illustrated here in relation to multiliteracies, can be addressed by reflection on how researchers position themselves, and the theories and data they are working with. 
Calls to reflexivity, including as part of Street's hidden features, focus on the distinctive perspective, engagements and history of the individual author. It is even more important to interrogate "the epistemic history and unconscious of the field" rather than "the apparently idiosyncratic view points of the individual researcher" (KENWAY; MCLEOD, 2004, p. 528).

A number of classic critical literacy questions can be helpful for the task of interrogating the wider field: whose voices are privileged? Whose voices are excluded? How do I position myself and my work in relation to authoritative voices? On what basis do I grant authority to ideas and theories in my writing? Such questions can also be usefully reworked within the categories that Street lays out for his analysis of hidden features, borrowing the language of fields. In Table 1 below, I add questions that seek to address the issues identified in previous sections to Street's six categories (there is some overlap in these).

TABLE 1 - (Re)Positioning Epistemological Stances: a mapping of critical reflection questions onto Street's Hidden Features framework

\section{Framing: Genre Audience}

How does my writing reflect and claim a different position from that produced in the metropole?

How do I acknowledge and position myself in relation to local, northern and southern audiences?

Contribution / "so what?" To knowledge; To field; To future directions / research

To whom do I seek to demonstrate the value of my contribution?

Whose knowledge am I building on? Whose interests does this knowledge serve?

What knowledge is valued and marginalised in the field to which I seek to contribute?

How and by whom is this field defined? Where is this field located? To what realities does it speak?

Am I assuming a contribution to a single, unified transnational field in my writing?

Where and for whom are future directions to be located?

What ends is my research serving? Who do I seek to benefit?

What body of knowledge most speaks to the realities I seek to interpret? 


\section{Voice}

Does my 'voice' make it clear that I have commitments outside of the metropolitan intellectual field?

Do I position myself as a producer of theory or merely an applier to new terrain?

Do I consider my various commitments as valid sources of a plurality of knowledge and epistemology?

Am I able to affirm my identity and authority as founded in fields beyond the metropolitan intellectual field?

Stance Person/ Agency Reflexivity

Does my credibility rely on my ability to project myself as a member of the metropole?

Is my authority based on contributing to northern concerns and interests?

Is my involvement as an author based on the realities my text seeks to address?

Do I problematize northern epistemologies?

\section{Signalling Setting Theory Method}

Does my signalling identify or locate important information (spatially, temporally)?

Are extensions of concepts to new settings or applications recognised as such?

Structure Opening (Vignette, Personal, Declarative), Setting, Theory, Methods, Conclusions

Will bracketing into traditional structural elements impede my ability to position my work as a critical contribution to multiple fields?

How can I make sure that the "setting" is considered in relation to theory and methods?

How can I organise my engagement with the literature(s) critically in order to position it and my engagement with it?

How can I establish myself as a theorist, not merely a craftsperson applying theory with "fidelity" and "reliability"?

These questions are useful as part of the academic writing process and in the teaching of academic literacies. They are valuable not just for those working in developing countries, but also for those writing from the developed centres of knowledge production. It is hoped that they can contribute to the development and expression of reflexive epistemologies in critical applied linguistics. 
Reflections on (re)positioning academic work are valuable not just to think about the north-south dynamic in knowledge production, but also to think about the distinctive position of researchers as a privileged category within the societies they seek to study. The realities addressed in the global north and south are distinctive, but so too (perhaps more so) are the experiences of university workers relative to the diverse or disadvantaged social groups contemplated by critical applied linguistics. In Brazil, for example, a country with a majority Black population, over $99 \%$ of academic staff in the largest public universities are white (SILVEIRA, 2016).

\section{Conclusion}

This paper is written from the perspective of someone who contributes to multiliteracies research in Brazil, and considers that it has much to offer. Critical applied linguistics, including the multiliteracies framework, espouses the kinds of goals that have the potential to support a more democratic debate and more situated theorising. The epistemological challenge for critical applied linguistics is to break with the narrative of a globally transforming society that knits together northern theory and southern data.

Global academic production in applied linguistics illustrates a number of epistemological challenges outlined by Pennycook (2001). The first of these is a kind of universalism that fails to recognise the limits of its own truth claims. Critiques of global knowledge production suggest a major weakness is a tendency to "read out" frameworks developed for developed nations (CONNELL, 2007; SOUSA SANTOS, 2003). The multiliteracies framework is not immune from this problem, either in its original form or in the Brazilian work that uses it. However, a second problem is shared by Pennycook's own preferred theoretical mode, steeped in postmodern and postcolonial "problematising." That is the privileging of discursive forms of power over histories and current realities of power enacted through violence and coercion - Brazil being an extreme case. More direct and brutal manifestations of coercive power are often left out or understated as Brazilian multiliteracies writing, not because authors are unaware of their importance, but because the critical applied linguistic tool-kit produced in the global north does not account for them adequately.

It is important for writers to seek a critical applied linguistics to more explicitly position epistemological frameworks within which they set 
up their work, as well as reposition themselves as occupying a distinctive and productive epistemological location. Without greater support from "southern" analysis of the forms of power, exploitation and control that characterise imperialism and colonialism, scholars are reduced to hollow calls for cross-cultural communication and harmony. To meet this challenge requires increased south-south dialogue through forums involving Latin American, African and Asian scholars. While some forums of this nature do exist, they are devalued within the current institutional and political framework of academic internationalisation. The World Social Forum is an example of the fact that somewhere in the world this kind of work has been undertaken, as is the case of the International Congress on Southern Epistemologies, hosted by the Federal University for Latin American Integration (UNILA) in late 2016. This conference brought together scholars to counteract the totalizing theoretical hegemony of Anglo-American scholarship by drawing on theoretical insights gained in other languages in other cultures, including the fields of philosophy (José Guadalupe Gandarilla Salgado) and geography (Tatiana Tramontani Ramos). UNILA itself seeks to stand for an ideal of south-south dialogue, being a multilingual institution located at the point where the borders of Brazil, Argentina and Paraguay meet. Although there are some avenues for the exchange of ideas across languages - Spanish and Portuguese, in Latin American journals, for example - the global linguistic and academic markets grant these low prestige and legitimacy.

Part of the struggle, therefore, must be for institutional recognition and legitimation of alternative forums and forms - this includes alternative criteria for assessing quality and relevance. Central to this task is creating the conditions for an academic field of production that, to repeat Hyland's formula, allows for different ways of communicating "integrity, credibility, involvement, and a relationship to the subject matter and [our] readers" (HYLAND, 1999, p. 99). To refine and reposition academic production beyond a north-south academic dichotomy, it is essential to look to the ideas and needs emerging from social struggles in order to reorient our thinking to perform the work of organic intellectuals, not merely institutional intellectuals. In 2016, over 1,000 Brazilian schools and 82 universities were occupied by students protesting against a 20 -year freeze on public spending. This is producing different kinds of learning activities and spaces, and a different set of relationships among students, teachers and the 
community. These experiences are also produced through distinctive forms of networked communication, through alternative media organisations and online communities, reflecting a new set of priorities and interests. These concerns and demands, relating directly to issues of recognition, dignity and rights for oppressed groups, must be translated into epistemological grounding for academic production.

\section{Bibliography}

APPADURAI, A. Disjuncture and difference in the global cultural economy. Theory, Culture and Society, v. 7, n. 2, p. 295-310, 1990. https://doi. org/10.1177/026327690007002017.

BAGNO, M. Preconceito lingüistico: o que é, como se faz. São Paulo: Edições Loyola, 1999.

BAGNO, M. Genocídio, Migração Forçada e Contato na Formação do Português Brasileiro. Capoeira-Humanidades e Letras, v. 1, n. 1, p. 4-14, 2014.

BAPTIST, E. The half has never been told: Slavery and the making of American capitalism. New York: Basic books, 2014.

BLOMMAERT, J.; RAMPTON, B. Language and superdiversity. Diversities, v. 13, n. 2, p. 1-21, 2011. Available at: <http://www.mmg.mpg.de/fileadmin/user_ upload/Subsites/Diversities/Journals_2011/2011_13-02_art1.pdf $>$. Retreived on: Nov. 12, 2016.

BOUFLEUR, R. N. A questão da gambiarra. São Paulo: Faculdade de Arquitetura e Urbanismo (USP), 2007.

CANAGARAJAH, A. S. A geopolitics of academic writing. Pittsburgh: University of Pittsburgh Press, 2002.

CONNELL, R. W. Southern theory: The global dynamics of knowledge in social science. Cambridge: Polity, 2007.

COPE, B.; KALANTZIS, M. Multiliteracies: Literacy learning and the design of social futures. New York: Routledge, 1999.

COPE, B.; KALANTZIS, M. Multiliteracies: Literacy learning and the design of social futures. London: Psychology Press, 2000.

COPE, B.; KALANTZIS, M. "Multiliteracies": New literacies, new learning. Pedagogies: An International Journal, v. 4, n. 3, p. 164-195, 2009. https://doi. org/10.1080/15544800903076044. 
DE SOUZA, L. M. T. M. Entering a culture quietly: writing and cultural survival in indigenous education in Brazil. In: MAKONI, S.; PENNYCOOK, A. (Org.). Disinventing and reconstituting languages. London: Multilingual Matters, 2006. p.135-69. ESCOBAR, A. Development, violence and the new imperial order. Development, v. 47, n. 1, p. 15-21, 2004. https://doi.org/10.1057/palgrave.development.1100014. FORUM BRASILEIRO DE SEGURANCA PUBLICA. Anuário Brasileiro de Segurança Pública. São Paulo: Forum Brasileiro de Seguranca Publica, 2015.

GALEANO, E. The Open Veins of Latin America. Melbourne: Scribe, 2009.

GEE, J. P.; HULL, G. A.; LANKSHEAR, C. The new work order: Behind the language of the new capitalism. Boulder: Westview Press, 1996.

GOMES, A. M.; ROBERTSON, S. L.; DALE, R. The social condition of higher education: globalisation and (beyond) regionalisation in Latin America. Globalisation, Societies and Education, v. 10, n. 2, p. 221-245, 2012. https://doi.org/10.1080/1476 7724.2012.677708.

GRAMSCI, A. Selections from the prison notebooks of Antonio Gramsci. London: Lawrence \& Wishart, 1971.

HOOKS, B. Teaching to transgress: education as the practice of freedom. New York: Routledge, 1994.

HYLAND, K. Disciplinary discourses: Writer stance in research articles. In: CANDLIN, C.; HYLAND, K. (Org.). Writing: Texts, processes and practices. London: Longman, 1999. p.99-121.

IYER, R. et al. Critical applied linguistics. In: LEUNG, C.; STREET, B. (Org.). The Routledge Companion to English Studies. New York: Routledge, 2014. p.317-332.

KENWAY, J.; MCLEOD, J. Bourdieu's reflexive sociology and 'spaces of points of view': whose reflexivity, which perspective? British Journal of Sociology of Education, v. 25, n. 4, p. 525-544, 2004. https://doi.org/10.1080/0142569042000236998.

KLEIN, H. S. The Atlantic slave trade. Cambridge: Cambridge University Press, 2010. https://doi.org/10.1017/CBO9780511779473.

KUMARAVADIVELU, B. A linguística aplicada na era da globalização. In: MOITA LOPES, L. P. (Org.). Por uma linguística aplicada indisciplinar. São Paulo: Parábola, 2006. p.129-148.

LEITE, D. Brazilian higher education from a post-colonial perspective. Globalisation, Societies and Education, v. 8, n. 2, p. 219-233, 2010. https://doi. org/10.1080/14767721003779738.

LIPMAN, P. The new political economy of urban education: Neoliberalism, race, and the right to the city. New York: Taylor \& Francis, 2011. 
LUCCHESI, D. O conceito de transmissão linguística irregular e o processo de formação do português do Brasil. In: RONCARATI, C.; ABRAÇADO, J. (Org.). Português brasileiro: contato linguístico, heterogeneidade e história. Rio de Janeiro: 7Letras, 2003. p.272-284.

LUCCHESI, D. Lingua e Sociedade Partidas: a Polarização Sociolinguística do Brasil. São Paulo: Contexto, 2015.

MIGNOLO, W. Capitalism and geopolitics of knowledge: Latin American social thought and Latino/a American studies. In: POBLETE, J. (Org.). Critical Latin American and Latino studies. Minneapolis: University of Minnesota Press, 2003. p. 32-75.

MIGNOLO, W. The Idea of Latin America. Malden: John Wiley \& Sons, 2009.

MIGNOLO, W. Local histories/global designs: Coloniality, subaltern knowledges, and border thinking. Princeton: Princeton University Press, 2012. https://doi. org/10.1515/9781400845064.

PAVLENKO, A. Superdiversity and why it isn't. In: Sloganizations in Language Education Discourse conference, 2014, Berlin. Proceedings p.8-10.

PENNYCOOK, A. Critical applied linguistics: A critical introduction. New York: Routledge, 2001.

PENNYCOOK, A. Critical and alternative directions in applied linguistics. Australian Review of Applied Linguistics, v. 33, n. 2, p. 1-16, 2010. https://doi. org/10.2104/aral1016.

RAJAGOPALAN, K. Por uma lingüistica crítica: linguagem, identidade e a questão ética. São Paulo: Parábola, 2003.

REUTERS. Violent deaths in Brazil surge to peak of 58,000 amid Olympic safety fears. The Guardian, 2015.

ROMÃO, J.; CARVALHO, A. A. Negros e Educação em Santa Catarina: retratos de exclusão, invisibilidade e resistência. In: DALLABRIDA, N. (Org.). Mosaico de Escolas: modos de educação na primeira república. Florianópolis: Cidade Futura, 2003.

ROSAS, R. Gambiarra: alguns pontos para se pensar uma tecnologia recombinante. Caderno Videobrasil, v. 2, p. 36-53, 2006.

SAID, E. Orientalism. New York: Penguin, 1995.

SILVEIRA, A. A intelectualidade negra e a invisibilidade nos espaços acadêmicos. Blogueiras Negras, 13/08/2016. Available at: < http://blogueirasnegras.org/2014/10/28/aintelectualidade-negra-e-a-invisibilidade-nos-espacos-academicos $/>$. Retrieved on: Oct. 15, 2016. 
SOUSA SANTOS, B. The World Social Forum: A User's Manual, 2003. Available at: <http://www.ces.uc.pt/bss/documentos/fsm_eng.pdf>. Retreived on: Jan. 20, 2012.

SPIVAK, G. C. Can the subaltern speak? In: NELSON, C.; GROSSMAN, L (Ed.). Marxism and the Interpretation of Culture. Urbana: Springer, 1988. p.271-313. https:// doi.org/10.1007/978-1-349-19059-1_20.

SPIVAK, G. C. A critique of postcolonial reason. Cambridge: Harvard University Press, 1999.

STREET, B. " Hidden" Features of Academic Paper Writing. Working Papers in Educational Linguistics (WPEL), v. 24, n. 1, p. 1, 2009.

THE NEW LONDON GROUP. A pedagogy of multiliteracies: Designing social futures. Harvard educational review, v. 66, n. 1, p. 60-93, 1996. https://doi. org/10.17763/haer.66.1.17370n67v22j160u.

WILLIAMS, E. Capitalism and slavery. Chapel Hill: UNC Press Books, 2014.

WINDLE, J. A.; MILLER, J. Approaches to teaching low literacy refugeebackground students. Australian Journal of Language and Literacy, v. 35, n. 3, p. 317333, 2012.

Data de submissão: 13/08/2016. Data de aprovação: 13/02/2017. 